\title{
Memória, verdade e justiça como luta ética
}

\author{
Memory, truth and justice as an ethical struggle
}

\author{
Cecilia Maria Pinto Pires*
}

\section{Resumo}

O presente artigo apresenta uma análise sobre os elementos atuais da luta pelos direitos humanos, com ênfase no resgate da memória e da verdade para que se faça justiça. A Justiça de Transição comparece hoje como uma referência acadêmica, ética e política.

Palavras-chave: Direitos Humanos. Memória. Verdade. Justiça. Ética.

\section{Abstract}

This paper presents an analysis of the current elements of the struggle for human rights, with emphasis on the recovery of memory and truth so that justice is done. The Transitional Justice appears today as an academic, political and ethics reference.

Keywords: Human Rights. Memory. Truth. Justice. Ethics.

\section{Introdução}

Este artigo analisa a motivação de uma luta ética nos processos de construção da memória, da verdade e da justiça. Essa proposta se dá no quadro de avanço da luta pelos direitos humanos nas sociedades que se sensibilizaram por esse tema. Em nosso país e no continente, é na organização da sociedade civil, em seu movimento de resistência

Professora no PPG Direito - IMED, na disciplina Teorias da Democracia. Pesquisadora na área de Filosofia Política, com estágio de Pós-Doutoramento na Sorbonne, Panthéon I - Paris. Doutora em Filosofia pela UFRJ, na área de Filosofia Social. Passo Fundo - RS - Brasil. E-mail: ceciliapires.pires@yahoo.com.br 
ao esquecimento da barbárie promovida por governos autoritários, que se situa o foco desse estudo. Esse propósito visa justificar a essência da democracia, que requer um tratamento civilizado dos cidadãos, com base na igualdade, pluralidade e liberdade.

Há um universo de saberes articulando os elementos factuais que destruíram a vida das pessoas nos anos de chumbo do Brasil. Articulamos nossos saberes com parcerias de outros lugares e outras experiências da tragédia humana, e isso nos identifica, no universo acadêmico e político, embasando e comprometendo os atores do enfrentamento da luta ética pela memória e pela verdade, para que se faça justiça. Nesse entendimento, temos atores e protagonistas que dinamizam os saberes construídos e necessariamente partilhados.

A violação de um direito humano diz respeito a uma compreensão universal do valor da vida humana. Por isso, não cabe apresentar soluções parciais, atinentes a determinada localização geográfica, ao problema da violação da lei pelos agentes da lei, atingindo a dignidade das pessoas através de procedimentos cruéis. A degradação da humanidade de um não se esgota na desumanização dele, mas, como degradação humana, atinge toda a humanidade. Não é permitido que se esqueça a violação, pois ela diz respeito à totalidade, aos humanos que habitam o planeta e gozam do direito em conjunto. O humano, a espécie, o sujeito do direito solidário, sente-se ofendido pelo desacato cometido em local específico a uma pessoa específica. Ofender a um é ofender a todos, pela circunstância própria da condição humana.

A racionalidade, ancorada no conceito de razão ética, intenciona produzir uma compreensão ampliada da práxis no universo dos sujeitos sociais, de forma a serem assumidas novas lutas do ponto de vista das vítimas. Os debates trazidos à cena reflexiva procuram sublinhar a importância da organização da cidadania, na sociedade civil, para que aconteçam interrupções sequenciais nas instâncias de dominação, como as esferas do poder, e em todos os âmbitos organizativos que impeçam a autonomia da razão e o protagonismo dos sujeitos que lutam pela Verdade como condição de Justiça. 
Na história da repressão em nosso país e em nosso continente, as nacionalidades viveram um cotidiano de miserabilidade e indigência éticas, que apontaram algumas urgências, como o reconhecimento das vítimas e a culpabilidade do Estado.

Desse modo, ações como as promovidas pela Justiça Restaurativa garantem a afirmação da razão ética como realização necessária do compromisso e responsabilidade sociais. Acontece, então, o momento do enfrentamento estratégico, a luta ética, que se respalda na exigência de respeito a direitos e na efetividade da memória, da verdade e da justiça. Há o reconhecimento da dignidade dos sujeitos, libertando-os de formas conceituais, trazendo-os à história e maximizando a cidadania.

\section{A dimensão dos direitos humanos na atualidade}

Motivos para uma luta ética é o que nos propomos a debater neste texto. É do conhecimento de todos o avanço da luta pelos direitos humanos nas sociedades que se sensibilizaram pela violação deles. Em nosso país, como nos demais países do nosso continente, afetados por governos autoritários, a organização da sociedade civil movimenta-se para uma dimensão de resistência ao esquecimento. Atualmente, vividas e reconhecidas as pautas de ação social propostas pelos pioneiros no que se refere aos direitos fundamentais ${ }^{1}$, apresentam-se conjunturas que evidenciam um universo de vítimas no período mais cruel do regime autoritário.

\footnotetext{
As expressões "direitos humanos" e "direitos fundamentais" não colidem, embora tenham suas especificidades. A primeira diz respeito ao caráter ético-universal da ideia de direitos e precede qualquer ordenamento jurídico estatal. Tem uma validez para todos os povos, independente de qualquer temporalidade histórica. A segunda se refere aos estabelecimentos constitucionais dos Estados e Nações, com suas particularidades legais, cuja vinculação normativa está afeta ao âmbito do Direito Constitucional. Sobre esse tema, ver SARLET, Ingo Wolfgang. A eficácia dos direitos fundamentais: uma teoria geral dos direitos fundamentais na perspectiva constitucional. Porto Alegre: Livraria do Advogado Editora, 2009 e Dignidade da Pessoa Humana e Direitos Fundamentais na Constituição Federal de 1988. Porto Alegre: Livraria do Advogado Editora, 2009. Ver, também, COMPARATO, Fabio Konder Fundamento dos Direitos Humanos. Instituto de Estudos avançados, IEA, Universidade de São Paulo, São Paulo, 1997, vol. 30 e CANOTILHO, José J. Gomes. Direito Constitucional. Coimbra: Almedina, 1992.
} 
Temos a condição de refletir sobre o que aniquilou os sujeitos nessa etapa autoritária do Estado brasileiro. Os momentos em que o terror se tornou apoteótico ensejam o desejo de justiça por parte das vítimas, pessoas que não podem ser olvidadas pela sociedade civil. Elas merecem ser resgatadas em sua honra cidadã.

Articulamos esses nossos saberes com parcerias de outros lugares e outras experiências da tragédia humana. Isso nos identifica no marco da construção de um universo acadêmico e de um universo político, que nos compromete no enfrentamento desse desafio: a luta ética pela memória e pela verdade, para que se faça justiça.

Ao refletirmos sobre as situações vividas pela nossa história recente, somos movidos por interesses de interlocução, cuja validez ultrapassa o mero cumprimento formal dos atos de fala. Queremos pensar sobre as ações da humanidade, o que fizemos e como fizemos, e dessa forma reafirmar as regulações atuais na esfera dos direitos fundamentais assumidos pelos povos e nações.

Saliente-se que os direitos humanos trazem o conteúdo ético da ideia de valor. Na explicitação de seus postulados, revelam-se os valores, fundamentados nas próprias exigências das pessoas que tomam consciência do aviltamento de suas subjetividades e se indignam exigindo que a justiça aconteça, a partir de um reordenamento social. Tais direitos buscam uma razão, que se qualifica como razão ética, cujo desiderato visa o fortalecimento de uma ética de compromisso com a cidadania.

Assim nos posicionamos acerca das posturas éticas e da vivência política, construindo cidadania e democracia:

A cidadania quando assumida na sua plenitude, evidencia uma atitude de resistência face aos problemas que aviltam a dignidade do ser humano. Isso significa assumir uma razão ética na vida pública, ao dizer não para um conjunto de circunstâncias e dizer sim para outro conjunto que se entende válido, afirmativo na defesa dos direitos da humanidade. Cabe referir que o avanço da democracia 
na América Latina e nos demais continentes deve-se a ações de sujeitos que não optaram pelo silêncio cauteloso, mas decidiram acreditar numa ação conjunta, para produzir condições de vida digna, são os que vinculam o compromisso ético com a ação cidadã. (PIRES, 2011, p. 67)

Nesse entendimento, temos atores e protagonistas que dinamizam os saberes construídos e necessariamente partilhados, no cumprimento de um dever social de cidadania, que é o alargamento desses saberes para além das fronteiras geopolíticas, uma vez que a violação de um direito humano diz respeito a uma compreensão universal do valor da vida humana. Esse deve ser também o entendimento, para que se efetive a justiça como compromisso com a vida ética.

A dimensão própria de uma luta pela memória e verdade, a partir de uma perspectiva de justiça, requer uma dinâmica de ação em que os protagonistas explicitem seus interesses, desejos, vontades e, sobretudo, manifestem suas competências na elaboração teórica e eficácia prática. Aqui, cabe considerar as vítimas e seus familiares como protagonistas inseridos numa perplexidade em que os homens se tornaram estranhos uns para os outros. Como se registram os fatos do ponto de vista das vítimas? E quem são as vítimas?

Em princípio, as vítimas são o alvo de toda e qualquer espécie de violência. Violência sempre resulta em vítimas e, em se tratando da ação dos agentes de um Estado autoritário, a questão toma maiores proporções.

Tal constatação nos remete ao imaginário dos algozes, que sabiam efetivamente o que estavam fazendo ao tentarem destruir a resistência de suas vítimas, e que hoje tentam comparecer na mídia, justificando a lealdade a um Estado violador de direitos. Eles também apresentam uma elaboração teórica e uma eficácia prática, com vistas a se tornarem inteligíveis em seus atos.

A humanidade evoluiu, caminhou gradativamente para o reconhecimento dos direitos humanos. No entanto, as regiões de conflito acerca de tais direitos ainda permanecem com suas tensões 
peculiares, como a questão da pena de morte, da morte pela fome como irresponsabilidade do Estado (num flagrante descompromisso com o cidadão), a violação das fronteiras, as invasões e dominações culturais, as atitudes racistas e discriminatórias contra as etnias, a dominação dos imaginários religioso e político, a expropriação das riquezas coletivas pelas individualidades da arrogância e da prepotência do sistema capitalista, para citarmos o que é o mais cruel nesse período contemporâneo.

Ainda assim, os direitos humanos buscam uma razão, que se qualifica como razão ética, sem o interesse de aparecer como uma razão de dominação. Mais do que nunca, é preciso situar a questão ética no espaço histórico do homem, porque a história é a expressão dos caminhos da humanidade, logo, é o espaço manifesto de seus valores e de suas escolhas.

Não há que ser assumida nenhuma fala de dominação na relação de ajuda para a interrupção dessa barbárie cotidiana. É preciso vivenciar uma espécie de sabedoria ética, que enseje agrupamento de forças políticas, face à necessidade prática acumulativa de resultados.

Os meninos de rua, as mulheres violentadas, os negros discriminados, os sujeitos famintos querem sair desse mundo dantesco e precisam encontrar juntos elementos que Ihes indiquem a possibilidade de saída. A eles não interessa o êxito de tal facção ou agrupamento partidário, eclesial, educacional ou empresarial. As suas urgências são as originárias para que se saibam sujeitos, para que construam sua autonomia.

Zamora (2008, p. 99) define os vínculos entre indivíduo e autonomia:

O conceito de indivíduo está associado, ao menos desde a Modernidade, à capacidade de autoconsciência de autodeterminação e de auto-expressão dos seres humanos na qualidade de membros da sociedade. Trata-se de capacidades adquiridas graças à mediação social, mas também em tensão e resistência frente a ela. $O$ indivíduo se constitui por meio da autonomia, se identifica praticamente 
com ela. Assim, pois, é a sociedade burguesa que possibilita e, ao mesmo tempo, exige de cada um de seus membros que sejam indivíduos autônomos no sentido de que façam valer seus interesses políticos e econômicos e de que sejam responsáveis por si mesmos. Essa responsabilidade afeta inclusive o âmbito dos desejos e da expressividade, que também descansa sobre os indivíduos o próprio projeto de auto-realização, de felicidade.

A construção e a afirmação dessa autonomia requerem no espaço público uma responsabilidade civil que não pode ser transferida a outrem, sob pena de uma menoridade da razão, o que impediria o seu uso público, segundo a compreensão kantiana de autonomia da razão. Autônomo é o sujeito que pensa por si mesmo, que não necessita de tutores para guiarem seus passos.

Originariamente, autonomia ${ }^{2}$ significa um poder pessoal sobre si mesmo, uma capacidade de autogoverno, de autogerenciamento, ou seja, a pessoa autônoma dispensa aconselhamentos secundários e até principais, pois sabe de si, de seus valores, de suas escolhas, dos caminhos que necessita percorrer para atingir seus fins, suas metas.

No que se refere à vida em sociedade, o cidadão necessita saber pensar, saber agir e se capacitar para entender do que a sociedade está precisando. Além disso, a sabedoria autônoma requer serenidade, o que significa compreender o melhor momento de fazer tal coisa, que possa resultar em benefício de todos, pois do contrário o esforço da ação se torna inútil, quando os sujeitos seguem impulsos momentâneos, sem maiores reflexões.

As implicações filosóficas de um enfrentamento político contra a violência, a favor da vida, explicitam-se na própria compreensão da subjetividade e da ampliação dessa consciência, face aos impasses e perspectivas. Saber pensar e saber agir são situações definitivas da maioridade pública.

2 Autonomia é um vocábulo grego que indica a ideia de lei própria. Nomos é lei; auto diz respeito a si mesmo. 


\section{0 respeito às vítimas, a revelação da verdade}

Sirvo-me, para ilustração teórica, da famosa tragédia grega Antígona, de Sófocles, para suporte de análise no debate ético sobre as vítimas. Ela narra que dois filhos de Édipo, Etéocles e Polinices, mataramse mutuamente em busca do trono de Tebas. Com isso, Creonte sobe ao poder e faz determinações sobre o sepultamento dos dois irmãos. Etéocles seria sepultado com todo o cerimonial devido aos mortos, pois lutou em prol do governo; Polinices não teria o direito de ser sepultado, sendo seu corpo abandonado para ser devorado pelas aves de rapina, como punição por estar contra o governo. Creonte, o tirano, entendia que isso serviria de exemplo para os que se rebelassem contra o governo de Tebas.

Antígona não aceita a decisão do tirano Creonte e decide enterrar o corpo do seu irmão, ainda que isso Ihe custe a própria vida. Aparece o confronto entre as leis do Estado e os interesses dos cidadãos. Na lógica do tirano, ninguém poderia desobedecer às suas ordens, e Antígona é punida por desacatar as leis terrenas, afirmando as leis dos deuses, cultuados na dimensão da vida privada. Ali ocorreu o episódio de uma subjetividade amordaçada pelo poder do Estado.

Esse fato nos leva a refletir sobre o direito que as vítimas e seus familiares têm de enterrar seus mortos, ainda que as decisões do Estado sejam diferentes. Toda luta ética pela memória e verdade, o que implica em justiça, requer o respeito às vítimas, na plenitude de uma memória de respeito e de não-esquecimento.

A compreensão da memória como não ocultamento de uma verdade histórica exige relações de unidade entre discurso e ação, uma vez que não bastam os arquivos de uma memória oficial, a qual pode manipular os elementos significantes das injúrias e desonras que atingem as vítimas.

Se não existir o desvelamento da verdade, a memória trai a história e afasta a humanidade das possíveis compreensões acerca do que ocorre, quando se rompe o laço social. Hannah Arendt reitera que 
o laço com a tradição possui uma debilidade - o esquecimento -, e isso produz um não direcionamento do presente, pelo fato de o passado não estar recomposto na memória, ficando inviável a perspectiva de futuro. Houve uma herança sem um testamento que a direcionasse ${ }^{3}$, produzindo uma lacuna entre o passado e o futuro. Escondeu-se um tesouro: o encontro dos sujeitos com sua própria história.

Isto porque a memória, que é apenas um dos modos do pensamento, embora dos mais importantes, é impotente fora de um quadro de referência preestabelecido, e somente em raríssimas ocasiões a mente humana é capaz de reter algo inteiramente desconexo. Assim é que os primeiros a fracassarem no recordar como era o tesouro foram precisamente aqueles que o haviam possuido e o acharam tão estranho que nem sequer souberam como nomeá-lo. (ARENDT, 2003, p. 31)

$\mathrm{Na}$ verdade, o que a autora escolhe como alvo de análise é o fato de que o esquecimento desvincula a realidade da reflexão. Os acontecimentos podem repetir-se e vitimarem a humanidade novamente, e a ausência de uma compreensão sistêmica do passado, a crítica não realizada a respeito do que nos foi legado como herança, pode levar a um novo aniquilamento. Há uma inútil condenação à razão, que foi cúmplice de um holocausto, mas que não consegue tornar a realidade translúcida para ser entendida.

Essa ruptura do laço que sustenta a tradição e vincula passado e futuro torna-se uma efetividade histórica, produzindo perplexidades entre os atores sociais e configura-se, segundo Arendt (2003, p. 40), "um fato de importância política".

Desse modo, a sociedade tem o dever e o direito de interrogar o Estado a respeito dos arquivos em que os dados estão registrados e até mesmo interpretados. Os avanços possíveis que ocorreram nas

\footnotetext{
3 Arendt ilustra essa questão com o aforismo de René Char: Nossa herança nos foi deixada sem nenhum testamento. Comenta que o escritor francês da época da Resistência manifestou sua perplexidade diante do descalabro que ocorreu, a separação entre o vivido e o pensado.
} 
diferentes repúblicas democráticas se deve a essa necessária unidade entre o que se fala e o modo como se age, questão da qual resultou, de formas diversas, a constituição das comissões de verdade e de reparação, trazendo a público a realidade fáctica do ocorrido com as vítimas. É uma forma de recuperar o laço social rompido e redirecioanr o presente.

Em relato do professor José Zalaquett, da Faculdade de Direito da Universidade do Chile, podemos constatar a importância das comissões de verdade para o resgate da memória e da verdade.

O Chile teve duas Comissões de Verdade. Uma chamada Comissão de Verdade e Reconciliação (1990-91), que teve como papel reconhecer as vitimas fatais e as circunstâncias em que morreram essas vítimas, e outra com o nome de Comissão sobre Repressão Política e Tortura, que funcionou até 2004 e conseguiu apurar 29.000 vítimas da prisão política. A importância do trabalho dessa Comissão foi esclarecer como verdade a tortura como método generalizado sobre os prisioneiros políticos. Nas palavras de Zalaquett (2011, p. 19), "tão importante quanto a busca da verdade é o reconhecimento dessa verdade que se encontra".

Esse reconhecimento faz parte da luta maior pela memória e verdade como justiça para as vítimas do Estado. Nessa mesma linha de raciocínio, o direito que têm as famílias de enterrar seus mortos é que movimentou a sociedade civil para reclamar dos responsáveis pelas ações de governo os corpos de seus familiares desaparecidos ou mortos, na medida em que foram capturados vivos.

No Brasil, o caso do deputado Rubens Paiva é paradigmático. Preso pela polícia política dos ditadores, apenas recentemente sua família teve notícias sobre sua prisão, mas seu corpo não foi entregue para ser sepultado dignamente. Foi negado a seus familiares e a tantos outros o direito de enterrarem seus mortos.

Sartre (1968, p. 61), em uma das crônicas sobre a ação da França na guerra da Argélia, dizia com veemência:

O fim da tortura não é só obrigar a falar, a trair: é necessário que a vítima se designe a si mesma, por seus gritos e por 
sua submissão, como uma besta humana. Aos olhos de todos e a seus próprios olhos. É necessário que sua traição a destrua e nos livre para sempre dela. O que cede a tortura não somente se obriga a falar; é imposto a ele para sempre um estatuto: o de sub-homem (Tradução nossa).

Aqui, podemos entrar no debate sobre as vítimas de torturas como o alvo do aniquilamento, aquele que foi criminalizado pelo delito de opinião, assim determinado pelos agentes do Estado autoritário. Pensar nas vítimas é pensar em pessoas sacrificadas, feridas e ofendidas. E a verdade sobre essa condição precisa ser desvelada, precisa ser buscada, reconhecida como fato histórico.

Há datas, circunstâncias, registros e pessoas envolvidas que atestam o vivido, o acontecido. Pensar na dimensão da verdade para que a Justiça aconteça é imprescindível para o estabelecimento de um Estado de Direito.

A ideia de reparação se inclui nesse argumento, uma vez que a transição para a democracia exige que o Estado se comprometa em reparar as violações individuais e coletivas, de modo a consolidar o elo social rompido pela violência. Isso se traduz na não-aceitação das decisões dos tiranos e conduz a esse movimento de trazer a reparação como política pública de reconhecimento das vítimas e responsabilização dos algozes.

O professor Claudio Nash Rojas (2010, p. 94-95), da Universidade do Chile, em um artigo sobre reparações por violações de direitos humanos, refere:

As reparações em processos de transição para a democracia não cumprem apenas um papel individual quanto à vítima objeto de reparação, mas têm papel significativo social, histórico e preventivo. Na verdade, a motivação para corrigir os casos de violações massivas e sistemáticas tem a ver com as vítimas, mas também é uma maneira de a sociedade proporcionar as bases sociais de convivência baseada no respeito pelos direitos humanos. 
Tais reparações não podem ater-se apenas a uma espécie de recompensa financeira, pois isto não apaga a dor das vítimas. A reparação requer pedido de perdão por parte do Estado às vítimas ou a seus familiares pelo dano causado, que não pode ser esquecido. As caravanas de anistia em nosso país têm cumprido esse relevante papel cívico, ético e político, restaurando a verdade pela memória do que tem sido possível relatar. Com isso, construiu-se e se afirmou o conceito de Justiça de Transição4. Silva Filho (2010, p. 31) assim se manifesta:

Quando se olha para os crimes do Estado a partir do enfoque da justiça de transição fica cristalino o fato de que tais crimes não cabem na lupa do direito penal. Eles precisam ser estudados e analisados com o aporte de outras áreas afins, como as relações internacionais, a ciência política, a sociologia, a história e a filosofia política e de outras áreas dentro do direito, como a criminologia e, principalmente, o direito internacional.

No direito penal internacional constata-se uma lógica e uma cadência muito diferentes em relação ao direito penal interno. Importante registrar que, em sua grande parte, os crimes do Estado são crimes internacionais, assim definidos em tratados, convenções e outros documentos internacionais, logo, mesmo que o julgamento se dê em um órgão do judiciário nacional e não em alguma Corte internacional, ele invoca a dinâmica própria e as características presentes na esfera penal internacional.

4 Cf. Inês Virginia Prado Soares, Dicionário de Direitos Humanos. http://escola.mpu.mp.br/ . Sob a ótica da necessidade de reparação das vítimas e atendimento de suas expectativas, a justiça de transição foi diretamente influenciada pela atuação das organizações defensoras dos direitos humanos e pela normativa internacional (legislação de direitos humanos e legislação humanitária). Influenciada pelas experiências que se desenvolveram após a segunda metade do século XX em diversos Estados, a concepção de justiça de transição como um novo campo multidisciplinar baseado nos pilares de justiça, verdade, reparação e reformulação das instituições é consolidada no final dos anos 80 e princípio dos anos 90 como resposta às mudanças políticas e às demandas por justiça e verdade em países latino-americanos e da Europa oriental. (CENTRO INTERNACIONAL PARA JUSTICIA TRANSACIONAL, online, 2009). 
Há uma dialética no aparecer histórico da vítima-protagonista. Quem é a vítima da tortura política? É o protagonista da resistência ao arbítrio, o qual, em seguida, o alcança e o atinge.

Vítima, aqui, não se pode entender como aquele que, impotentemente, recebe o suplício aplicado pelo algoz. A vítima, nesse caso, é protagonista e só está sendo vitimado por conta do seu protagonismo. É o seu protagonismo de resistência ao poder arbitrário que coloca a nu a fraqueza do poder, que só é forte porque arbitra por cima do pacto social, da convivialidade e cordialidade social. Esse seu ato de resistência e desnudamento de um poder cuja maior fraqueza é o seu ato de força leva ao paroxismo o poderoso e libera todos os caudais da violência de Estado, contexto no qual a tortura, o aniquilamento, o banimento, o confinamento e o exílio são usados copiosamente.

A vítima é vitimada porque aponta o dedo ao poderoso e diz: tu és fraco, na tua fortaleza. O algoz se haure unicamente do círculo do poder e não emana do povo, de onde deve provir toda autoridade. Assim, a vítima-protagonista e o protagonista-vítima, ainda quando pisado e humilhado, atinge a consciência da nação, com a existência ou com a ausência, com a vida ou com a morte de seu corpo.

Nessa dialética sem síntese, o negativo assume um lugar maior, diminuindo a possibilidade da superação, sem o contraditório.

Zamora (2008, p. 262), na análise que faz do tema da dor em Adorno, assevera:

No entanto, a dor sempre se encontra inserida em um universo de significações socialmente construído que transcende o âmbito meramente privado. Que se sublinhe para uma completa determinação a partir de fora, que a possibilidade de compaixão e extrapolação seja, portanto, limitada, não quer dizer que seja absolutamente impossível a universalização por meio de uma analogia que não destrua a singularidade irredutível do sofrimento.

Nessa dialética entre o individual e o supraindividual, há o reconhecimento de uma razão negativa, que não se deixa impermeabilizar 
diante do sofrimento. Há, concretamente, um corpo que sofre e luta para não se tornar ausência.

Um corpo ausente não é um não-corpo, mas um corpo que diz: eu estava ali onde se fazia necessário, por isso não estou. O Estado que enfrentei tirou não apenas a mim, mas à família, não apenas à família, mas à nação, o meu direito de ser um corpo presente. O meu corpo ausente é a consciência nacional amputada, a fragmentação da informação histórica, a negação da memória coletiva. O meu eu renasce na ausência do meu corpo, no renascer da memória nacional, na explicitação da verdade sonegada. Aí aparece a possibilidade da síntese, ainda que seja pelo avesso da história.

Os registros da memória como integrantes da compreensão histórica permitem que entendamos além do relato narrativo das datas e calendários. É nesse sentido que a história humana é uma história da igualdade e da diferença. É evidente que tudo tem um custo; os acertos e erros sempre são muito bem lembrados e o mais inseguro é que nem sempre os homens controlam o resultado das ações que desencadeiam. Assim, como processo, a história humana é imponderável.

Arendt (1981, p. 245) adverte para essa questão:

O motivo pelo qual jamais podemos prever com segurança o resultado e o fim de qualquer ação é simplesmente que a ação não tem fim. O processo de um único ato pode prolongar-se, literalmente, até o fim dos tempos, até que a própria humanidade tenha chegado ao fim. Que os atos, mais que qualquer outro produto humano, tenham tão grande capacidade de perdurar constituiria motivo de orgulho para os homens se eles fossem capazes de suportar o ônus da irreversibilidade e da imprevisibilidade, das quais se origina a própria força do processo da ação. Mas, como a humanidade sempre soube, isto é impossível.

Ainda que haja esquecimento, não é possível ser desfeito o resultado de um ato, mesmo sendo um ato isolado. Isso se traduz no que a autora indica como a imprevisibilidade das ações humanas. Não 
temos domínio nem sobre as consequências nem sobre os motivos das nossas ações.

Se olharmos a história e considerarmos seus avanços, não podemos deixar de lado as vítimas e o entendimento de que seu sacrifício resultou até mesmo em conquistas para a humanidade. $\mathrm{O}$ exemplo de Giordano Bruno (queimado em 1600) é apenas um dos registros da memória. As lacunas culturais produzidas pela repressão política de qualquer ordem marcam o imaginário social dos povos e nações vitimados pelas experiências autoritárias e totalitárias.

\section{0 sentido da memória como construção da justiça}

Na análise da questão da memória, há necessidade de evidenciar a capacidade humana de elaborar juízos de valor, evidenciar as competências comunicativas, administrar os conflitos e construir relações de solidariedade com o futuro. Essa é a tarefa do presente: trazer os fatos do passado para dar continuidade à luta no futuro, mostrando que os fatos aviltantes não podem ser esquecidos e repetidos.

Cabe ressaltar aqui a importância da responsabilização dos que praticaram a violência. Essa é a condição da Justiça, que precisa investigar, interrogar, procurar entender a singularidade de cada atitude. Faz-se imprescindível, pois, o olhar de quem protege e abriga do desconforto, do medo produzido pela violência. O olhar de cuidado, de um sujeito com outro sujeito, possibilita curas.

A luta pela memória, verdade e justiça precisa demarcar onde aparece a violência do Estado como problema ético. Para que se entendam os motivos da luta pela memória e verdade, é preciso que se entendam as motivações dos verdugos. Nenhuma ação pela erradicação das ações de aniquilamento será eficiente se deixar ficar no olvido a sua dimensão ideológica, ou seja, aquilo que produziu os banidos políticos, os apátridas, os condenados à morte.

Busca-se apresentar uma racionalidade argumentativa, que destaque a justiça em seu conteúdo ético, evidenciando a ideia de valor. 
Essa ideia fundamenta as exigências próprias de pessoas que recusam a violação das suas subjetividades e postulam justiça, a partir de uma nova ordem econômica, política e social.

Tratar a questão da memória como construção da justiça, na sociedade civil, requer o entendimento de que é possível analisar as reivindicações dos cidadãos, no reconhecimento dos seus direitos. Uma das formas da governabilidade se realizar é a forma democrática, com tudo o que ela contém de avanço e de limite. Ainda não chegamos a um patamar satisfatório, no que se refere à experiência da democracia, nas sociedades modernas.

A razão ética, como uma postulação de compromisso e de responsabilidade civil, funda a democracia voltada para os valores humanistas. Não estamos dispensados de pensar novas alternativas para nossos povos e culturas, a relação entre o ético e o político, a lógica da alteridade, o reconhecimento de outros projetos emancipatórios. A partir desses desafios, é possível pensar a inclusão social, num modelo democrático de menor engessamento nas colunas do Estado.

As questões éticas e políticas que se apresentam no horizonte de um debate como esse envolvem o problema de uma democracia que inclua o sujeito, retirando-o da franja da marginalidade social, política, econômica e cultural. É uma saída da necessidade para a construção da liberdade. Aqui a memória pratica o não-esquecimento como uma dimensão da justiça.

Sabemos que, nesse particular, atingimos o problema da governabilidade, especialmente no que se busca entender como o gerenciamento da dívida histórica que devemos cobrar do Estado, como política pública, o reconhecimento das ações de violência e arbítrio, exigindo uma transparência na administração voltada para uma ética de responsabilidade pública, civil, democrática. Poderia, nessa configuração, alargar a perspectiva republicana, abrindo todos os arquivos necessários para que se conte a história verdadeira.

Os chamados poderes da república, articulados num tripé gerencial sobre a vida dos indivíduos, não impediram a discriminação, a injustiça 
e a supremacia do mais forte. Ao contrário, redobrou a guarda sobre os direitos de propriedade em detrimento dos direitos civis, políticos, culturais, econômicos e sociais.

Na motivação participativa dos cidadãos, vê-se, nos grandes países que movimentam os blocos econômicos, uma ausência deliberada de escolha, para não se comprometer com qualquer governabilidade, pois nenhuma formulação produz no espírito do indivíduo um sentimento de unidade e de competência. Esse vazio ético se apresenta no imaginário social como o grande argumento para a não participação.

Não há um juízo acerca dos governantes e seus epígonos. Eles estão protegidos por dezenas de leis, que não os levam aos tribunais; ainda que lá cheguem, não serão julgados com a severidade aplicada ao cidadão comum.

Uma das maiores homenagens que podemos fazer aos mortos e desaparecidos é não deixar os responsáveis pelas ações criminosas escondidos em armaduras de falsas defesas da pátria. Eles mentem e continuarão mentindo para deixar menores os seus crimes. Assim, já mataram Tiradentes, Marighella, Lamarca e continuarão produzindo novos extermínios se não forem contidos.

Lembramos de Arendt (2006, p. 16), quando mostra a mentira na política:

Mentiras são frequentemente mais plausíveis, mais clamantes à razão do que a realidade, uma vez que o mentiroso tem a grande vantagem de saber de antemão o que a plateia deseja ou espera ouvir. Ele prepara sua história com muito cuidado para consumo público, de modo a torná-la crível, já que a realidade tem o desconcertante hábito de nos defrontar com o inesperado para o qual não estamos preparados.

A luta ética pela memória e verdade para que ocorra a justiça visa denunciar e agir sobre uma violência praticada pelo Estado de Exceção, que utilizou a mentira como mecanismo de engodo para justificar seus atos. Faz-se imediatamente necessário avançar nas reivindicações 
atuais para que não se oculte mais nada da sociedade. Que possa a Comissão de Verdade ser respeitada e ouvida, a partir dos registros e depoimentos que conseguir coletar.

É evidente que isso exige a organização de um fórum permanente de estudos e ações para a superação da violência atual e que trate da questão nas mais diversas esferas sociais, políticas, econômicas, jurídicas e administrativas para se pensar na reforma do Estado, observando os interesses de todos os cidadãos, e não apenas de um segmento social, que usufrui do Estado de forma privada e reparte de forma pública o ônus dessa soberania.

Aliada a esse fórum, a sociedade civil, envolvida com a questão dos direitos humanos e da justiça, poderia ser motivada a pensar em políticas e estratégias para cultivar a paz. A necessidade - talvez a mais urgente, insistimos - é a de repensar o modelo de Estado e a forma de sua governabilidade, tentando apontar caminhos para o processo emancipatório dos sujeitos sociais.

A questão da soberania pública e da apropriação privada precisa extrapolar o viés acadêmico e atingir a materialidade do conflito sujeitos sociais/governo/estado/grande capital. Isso requer consolidar mais e melhor a liberdade e a igualdade como os pilares já reconhecidos da democracia.

As democracias atuais se ressentem da ausência do elo social. Há uma espécie de fragmentação na sociedade civil que se reflete nas formas da governabilidade do Estado, especialmente quando se trata de uma forma democrática com intenções emancipatórias, na esfera dos direitos humanos. A base dessa argumentação se firma nas experiências vividas pelas democracias modernas, que se mostraram, em suas fragilidades, avessas à justiça e ao direito.

Falar em razão ética e luta ética que motivem a construção de um novo tempo exige pensar as condições práticas dessa tarefa. E aí a democracia pode ser fortalecida, para além de uma mera intenção 
retórica de um discurso oficial. Pode e deve, pois se trata de enfrentar o instituído, estabelecendo os excluídos como o novo instituinte.

Abre-se, pois, um tempo de enfrentamento, e a práxis cobra da inteligência social a construção de uma nova democracia. A democracia como modelo de governabilidade necessita de uma razão, que se qualifica como razão ética. Essa é uma razão dos cidadãos que desejem usufruir os resultados da justiça.

Estamos realizando a experiência da compreensão histórica, que nos é permitida, ainda que haja restrições aos procedimentos investigativos dos fatos, o que não nos impede de prosseguir. Ao contrário, os postulados da Justiça de Transição podem reforçar o pleito da sociedade.

\section{Conclusão}

Mas quem somos? Quem nos atrevemos a ser? Qual coragem comanda nosso discurso e nossa ação? Que cidadania pretendemos construir após esse episódios de violência estatal? Novamente aparecem as perguntas identificadoras: quem é o sujeito histórico da ação social nesse recorte do tempo? Quem são os protagonistas da ação e do discurso, hoje, nesse cenário nacional? Questões como essas norteiam nosso perfil democrático para pensarmos um novo tempo, em que as vítimas possam ser honradas pela memória e pela verdade.

Para Hannah Arendt, não há relação de antinomia entre discurso e ação. Completam-se essas duas significações da presença humana na terra. A ação encontra seu fundamento no discurso, na medida em que ele revela sua intencionalidade. Não se trata de uma perspectiva iluminista, de rigorismo formal, cujo pensar estaria em patamar superior ao agir. $\mathrm{O}$ destaque é para o discurso e ação em consonância, pelas mediações que se realizam na construção da alteridade e no entendimento da singularidade. Estamos falando das subjetividades das vítimas. 
Inspirados na tese de Arendt, podemos inferir que na perspectiva da ação social reconstrutiva de uma nação é que se produzem as formas do fazer. Há um fazer pragmático, individualista, reduzido a trocas. Há um fazer da práxis, socializado, produtor de alternativas.

O fazer pragmático, positivado em tarefas, em situações imediatas, pode até estar desconectado das significações do sujeito histórico. Ocorre no âmbito do empírico, simplesmente. No entanto, o fazer da práxis, ampliado no vínculo com o elo social e acolhido no desejo de estar com os outros, necessita do discurso que revela o autor e o ator, ou seja, o protagonista da cena histórica e política. É mais do que uma conversa descomprometida, pois requer um interesse de transformação.

A intenção dessa análise acerca da memória e verdade soma-se à preocupação dos estudos contemporâneos sobre o tema, do ponto de vista das significações histórico-hermenêuticas. Castor Ruiz ${ }^{5}$ e Reyes Mate $^{6}$ são estudiosos que se destacam nas pesquisas sobre a justiça como fundamento da memória e da verdade. É a tentativa de congregar o discurso e a ação, momentos fortes do protagonismo social e político. Não se trata de uma interpretação negadora das lacunas conceituais, mas propositiva de significações interessadas na esfera dos Direitos.

Sabemos que o Estado precisa rever-se. Tornar-se menos burocrático e autoritário, permitindo que a sociedade organize a relação interativa na esfera pública, libertando-se das teias de falácias protetivas e inócuas. Daí a ideia de transformar a sociedade civil em uma comunidade democrática, na qual os sujeitos se relacionem

5 Nesse contexto, ressaltem-se estudos realizados por Castor Ruiz sobre a justiça em relação às vítimas e a memória como condição de reparação. Lê-se em os paradoxos da memória na crítica da violência que "o objetivo do surgimento histórico da memória foi trazer para o presente as consequências dos atos bárbaros cometidos pela violência no passado. O esquecimento naturaliza a violência. Foi a memória que mostrou para o presente as consequências da barbárie passada". (RUIZ, 2012, p. 39).

6 Conferir seus estudos em MATE, Reyes. Memórias de Auschwitz. São Leopoldo: Nova Harmonia, 2005 e La ética de las víctimas. Barcelona: Anthropos, 2003. 
dialogicamente, construam de modo autônomo seu pensamento e participem em condições de igualdade nos atrai. É esse o principal motivo, em nossa compreensão, pelo qual nós temos que estar empenhados na preservação da memória das vítimas para que a verdade se explicite.

Grandeza e absurdo se entrelaçam ao penetrarmos nos túneis escurecidos da história oficial, na clarividência de uma razão lúcida. A perplexidade pode invadir nossa inteligência, mas no minuto seguinte, superado o espanto a respeito do que os homens fizeram com os homens, temos que fortalecer nossa finitude num acordo solidário contra o extermínio dos que pensaram diferente da razão do Estado e por isso foram vitimados.

Temos dificuldade em lidar com o que nos parece absurdo. Fazemos a tentativa de lidar com o intolerável, com a tortura, por exemplo. E por mais que usemos toda a nossa carga racional para tentar entender os acontecimentos, lançando mão de outras explicações para ler as interfaces que aparecem na lógica das invenções humanas, não encontramos justificativa para o terror.

No que se refere especificamente à ética e à política, a razão do Estado se apresenta como soberana sobre a razão do sujeito. Assim, as subjetividades se aprisionam nos parâmetros institucionais, limites da normatividade legal, circunscrições ordenadoras da obediência civil.

Não faz parte da razão do Estado ir ao encontro da razão ética. Sua intenção é de tutoria, de administrar o bem-estar possível, realizando a fala do poder. A razão da sociedade civil precisa se fundamentar na razão ética para enfrentar a razão do Estado. Tudo isso, no entanto, exige um resgate valorativo da memória, para que se retirem os véus conciliadores próprios dos procedimentos pragmáticos.

A Justiça de Transição visa embasar seu juízo na acolhida às vítimas com o critério de restabelecer, pela memória e pela verdade, a exata dimensão das outras falas que não são apenas as falas dos protocolos da justiça comum. Surgida no cenário do século $X X$, no contexto dos governos totalitários, torna-se uma espécie de respiradouro, num ambiente afetado pelo simples formalismo das leis. 
Há que ser acolhido outro ponto de vista para o julgamento de extermínio político ou étnico. Afirma-se como parceira da ética nas fímbrias de um Estado-gerente e nessa construção de parcerias estabelece uma nova lógica sobre os parâmetros do Direito Penal. Ultrapassa as fronteiras geopolíticas, propiciando o uso dos recursos das Cortes e Tribunais Internacionais.

O desafio maior será, talvez, pensar a paz na perspectiva positiva, pois ela é sempre pensada negativamente, como ausência de guerra, como não-conflito, como inexistência da discórdia. A afirmação desse horizonte de paz, necessário para a sobrevivência do humano, requer o desejo e a vontade de pensar um novo modo de vida, além das experiências trágicas da humanidade, temperadas pela dor, pelo medo, pelo crime, pelo aniquilamento de povos e nações.

Nosso discurso e nossa ação têm que se apresentar como atitudes de partilha do poder e de compromisso com os direitos humanos em todos os seus avanços, para que não se acendam apenas as luzes do esclarecimento, mas também as luzes da cultura da paz.

\section{Referências}

ARENDT, Hannah. A Condição Humana. Rio de Janeiro: ForenseUniversitária, 1981.

. Entre o passado e o futuro. São Paulo: Perspectiva, 2003.

. Crises da República. São Paulo: Perspectiva, 2006.

CENTRO INTERNACIONAL PARA JUSTICIA TRANSACIONAL. ¿Qué es la justicia transicional? 2009. Disponível em: <https://www.ictj.org/ sites/default/files/ICTJ-Global-Transitional-Justice-2009-Spanish.pdf>. Acesso em: 08 ago. 2014.

PIRES, Cecilia M. Pinto. Direitos Humanos como proposta social: uma análise histórico-crítica. In: Fundamentos para educação em direitos humanos. Solon Viola e Marina Albuquerque (orgs.) São Leopoldo: Sinodal/EST, 2011. 
RUIZ, Castor M.M. Bartolomé (org.) Os paradoxos da memória na crítica da violência. In: Justiça e Memória. Direito à justiça, memória e reparação. A condição humana nos estados de exceção. Passo Fundo: IFIBE, 2012.

ROJAS, Claudio Nash. Reparações por violações de Direitos Humanos na jurisprudência da Corte Interamericana dos Direitos Humanos. In: Revista Anistia Política e Justiça de Transição. № 3, janeiro/junho, 2010. Dossiê Reparação. Brasília: Ministério da Justiça, 2010.

SARTRE, Jean-Paul. Colonialismo y Neocolonialismo. Situations V. Buenos Aires: Losada, 1968.

SILVA FILHO, José Carlos M. Crimes do Estado e Justiça de Transição. In: Sistema Penal \& Violência. Revista Eletrônica da Faculdade de Direito. PUCRS, Porto Alegre. N² 2, v.2, julho/dezembro, 2010.

ZALAQUETT, José. Verdade e Justiça em Perspectiva Comparada. (Entrevista a Marcelo Torelly). In: Revista Anistia Política e Justiça de Transição. $N^{\circ} 4$, julho/dezembro, 2010. Dossiê Justiça. Brasília: Ministério da Justiça, 2011.

ZAMORA, José Antonio. Th. W. Adorno. Pensar contra a barbárie. São Leopoldo: Nova Harmonia, 2008.

Recebido em: 22/09/2014

Aprovado em: 05/10/2014 